\title{
EXPLANATION OF PUBLIC FINANCE REFORMS IN POLAND
}

\section{Introduction}

The starting point for the analysis of the public finance architecture is doctrines on the state and law.

The form of public finance, its size, structure and redistribution methods depend on what has been accepted by the government and the political parties which are currently in power in a given state.

A specific form of public finance stirs specific emotions, discussions and controversies, as a result of which concepts of changes and reforms are formulated. However, justification must be sought for every reform and supporters of the new solutions, starting from the public to the groups of decision makers, must be won over. To make people accept the newly chartered course appropriate arguments are needed. This mechanism makes it worthwhile to analyze the direction of translational processes that heralded public finance reforms in the transition period in Poland. Naturally, such an analysis cannot be expected to be complete, because an allinclusive presentation of the outlined subject would require a much broader study, which is unfeasible within the scope permitted for this article.

In general terms, the necessity to implement a public finance reform is justified by references to certain doctrines upon which the state's functions are based.

According to the tradition of classical economics represented by Adam Smith, economy is dominated by the market, and so defense and protection should be the primary domains of state's activity.

A. Smith wrote that "The first duty of the sovereign, [is] that of protecting the society from the violence and invasion of other independent societies"1. "The second

1 A. Smith, Badania nad natura i przyczynami bogactwa narodów (An Inquiry into the Nature and Causes of the Wealth of Nations), PWN 1954, p. 399 
duty of the sovereign, [is] that of protecting [...] of every member of the society against injustice or oppression of every other member of it... "2. In the light of the quotations economic processes take place in the market and through the market, so it is not necessary for the state to "interfere" in the mechanism. This does not mean, however, that the government can take no action within a broadly understood public sphere that encompasses healthcare and security, education, culture, or welfare. All these domains perform their allocated functions via appropriate institutions that are frequently called the public benefit institutions. A. Smith believes that the above is another field where the state should be active. "The third and last duty of the sovereign or commonwealth is that of erecting and maintaining those public institutions and those public works, which, though they may be in the highest degree advantageous to a great society, are, however, of such a nature that the profit could never repay the expense to any individual or small number of individuals, and which it therefore cannot be expected that any individual or small number of individuals should erect or maintain." ${ }^{3}$. One of the effects is, for instance, that "...the course of education [goes] towards objects more useful, both to the individual and to the public, than those to which it would naturally have gone of its own accord"4.

All the quotations derived from the classical approach to economic processes make us raise the question, whether the approach entails a solution with two alternative lines of action: one increasing public revenue and the other reducing expenditure. A. Smith answers this question in the following way: "In order that the greater part of the members of any society should contribute to the public revenue in proportion to their respective expense, it does not seem necessary that every single article of that expense should be taxed." ${ }^{5}$ This statement can certainly be challenged, because there are many other approaches and perspectives on the discussed issues. Other proposals that appeared in the history of economic doctrines indicate that the role of the state should be treated differently. These doctrines are generally associated with state interventionism, whose prominent representative is Maynard Keynes, a determined opponent of laissez faire. Keynes proposes an active role of the state in economy, but the one respecting private ownership. He believes that a market system is not perfect, mainly because it is not fully capable of selfregulation. He considers economic processes globally, as a whole, without going into microeconomic details. Hence his position on the public finance sphere is that the high-income groups should be subject to progressive taxation, while the poorest provided with welfare benefits ${ }^{6}$. When an economy accepts state interventionism

Ibidem, p. 423

Ibidem, p. 441

Ibidem, p. 493

Ibidem, p. 669

I. Bludnik, Keynes i postkeysizm, w: Współczesne teorie ekonomii, collective works, M. Ratajczak (red.), Poznań 2007, p. 37 
then public expenditure must be adequately increased, with the following rise in the collected revenues. Because of the rise, resources available to the population shrink, likewise the citizens' disposable funds. Some economists claim that this mechanism constrains the economic freedom of societies and that placed between high taxes and substantial subsidies in favor of the public a state is thrown "out of gear"?

J. Buchanan opposes state interventions even in cases when the market fails. He argues that it is the citizen of a democratically organized society that decides what portions of their potential income should be allocated to public benefit ${ }^{8}$. At the same time, however, Buchanan doubts about the rationality of individuals' behavior'. The doubts are provoked by the relationship between the amount of public expenditure and the standard of living of population measured by so-called socio-economic indexes (Human Development Index - HDI). According to analyses, the two elements are not correlated ${ }^{10}$, which means that substantial public spending does not ultimately translate into society's well-being.

Nevertheless, public spending is high in many countries that want to retain state monopoly in many fields, such as healthcare, education, or the power industry, and this in many cases brings about crisis in public finance. To counteract such a scenario states take efforts to launch frequently ostensible reforms, that are intended to prevent a lack of acceptance for those in power. Therefore, some reforms can have a political background rather than economic. Accordingly, pertinent doctrines operate special condensed phrases intended to reflect the nature of the state, for instance, the classical economics uses ,a night watchman”; a social, welfare state (Sweden, FRG), or a partnership state (USA) are also used. This approach materializes as a slogan in many states today. Such state definitions are promoted also in Poland, especially during campaigns preceding parliamentary elections. The government formed in 2007 uses the term "friendly state", while the previous one stressed "low-cost state" These examples suggest that governments wish to share summarized knowledge about their plans with the society. In fact, however, the approach intends to explain the government's current or future public finance reforms, while winning over the society and public support for actions that in fact only pretend to be real reforms.

The attempts undertaken after the year 1990 to reform public finance can be divided into three stages.

The first distinct period is the years 1990-1993, when three important changes were made. In 1990 the institution of self-government was reinstated at the gmina (commune) level; two years later the personal income tax and corporate income

7 Vito Tanzi, Gospodarcza rola państwa w XXI wieku, NBP, Materiały i studia, fascicle no. 204, Warszawa 2006, p. 10

8 J. Buchanan, Finanse publiczne w warunkach demokracji, Warszawa 1997, p. 23

9 Ibidem, p. 25

10 V.Tanzi, op. cit, p. 9 
tax were brought in (1992), followed by the establishment of the tax on goods and services (i.e. VAT).

In the second period (1994-2004) reforms were implemented in three new areas. Firstly, the administrative division of the country changed with the introduction of three tiers: gminas (communes), poviats and self-governing voivodeships (provinces).

Secondly, the financial control over the healthcare system had been given to the Health Insurance Offices that after several years were transformed and renamed the National Health Fund.

And thirdly, the disability and old age pension systems were redesigned and based upon three pillars.

This catalogue of reforms can be extended by adding that in 1990 the Parliament enacted a law allowing the establishment of private educational institutions, thus opening door to the creation of private schools at the secondary and tertiary levels.

The third period of changes started in 2004 when Poland joined the European Union. At that time no institutional reforms were attempted within public finance, because the necessary harmonization of public finance systems across the European Union stressed financial instruments, mainly taxes, as the primary target of action.

The presented list of reforms makes us ask the question whether they were comprehensive, „sufficiently complete” in formal terms and coherent internally, whether their effects really improved the condition of public finance and, finally, whether they were consistent with the slogans spread to explain their necessity.

I believe that none of the mentioned reforms was thorough and well thought out. Because of their deficiencies the authorities had to adjust the lines of the reforms, sometimes deviating from the right, straight and logical course, and the reforms' translations frequently turned out to be contentless catchphrases that did not have much to do with real life.

The reform reinstating self-governing territorial units initially concentrated on establishing their lowest tier (the gminas). However, neither the concept of gminas' sources of finance was sufficiently elaborated, nor their tasks precisely defined. A perfect case in point is the school system. There were problems in deciding whether its control authority should be the central government, or perhaps local governments financed by educational subventions. In that period the slogan promoting decentralization of the state and of its system of government was emphasized the most strongly. All rough elements of the implemented changes were blamed on the conditions of the transitional period. In the pilot phase schools were transferred to 
the volunteering gminas, but then it was decided to make schools a mandatory task of gmina authorities.

Almost ten years later, in 1999, the reform of the administrative division of the country was resumed, and poviats and self-governing voivodeships were established. Long debates preceded determination of the number of the units for each of the tiers, as well as their areas. Another difficult problem to resolve was financial management in the units, particularly with regard to their sources of funding. As a result of the debates, it was initially decided that the units would be supported by the national budget allocations, enhanced by the units' own revenues. In this period the democratic character of the state was brought to the fore to justify the necessary reforms, while economic issues, such as projects extending beyond the area of one gmina (e.g. environmental undertakings), played a secondary role.

Changes in the healthcare system provide another example of the reforms. A system of Health Insurance Offices financed from both employers' and employees' contributions was introduced as late as 1999. The HIOs had an open, public character. Certain concerns prevented the authorities from introducing privately-owned HIOs. In addition to controversies over the level of contributions, the possible variety of HIOs was also disputed (an exception was separate HIOs for the military and police personnel). It is worth noting that the reform was delayed by more than a dozen of years, as its draft version had been developed already in the 1980s. Ultimately, the system was modeled after the German Krankenkasse, however some unjustified modifications were made to what had already been validated in Germany. The system for collecting contributions and controlling their ,inflow" remained unfinished, and the IT system calculating amounts accumulated on individuals' accounts was not built. As a consequence, the budget had to subsidize the HIOs that initially suffered from a shortage of funding. Additionally, the design of the basket of services available to the insured was not finalized. Chambers of the HIO Physicians empowered to supervise and verify payments made to physicians were not established, either. Still another problem was medicines and the payments for them.

Without waiting for the system to consolidate, including financial management in the HIOs, a change establishing the institution of the National Health Fund was introduced after a short time. The promoted explanation justified the decision by stressing the necessary improvement of the quality of healthcare services, their increased accessibility and smaller allocations to the HIO system perceived as a way of reducing the budget deficit. In this case the translation of the implemented line of action boiled down to "the rational state" slogan that alluded to a more coherent use of public funds.

The effects of actions undertaken within the healthcare reform can be succinctly described by the phrase "let's make it different if we can't make it better". 
The National Health Fund has not become a remedy improving the quality and accessibility of medical services. Hence participants of discussions following its establishment ponder whether the institution of HIOs could be restored, etc. In other words, the necessity to make more changes is indicated, even though the new system has not been precisely defined. This approach provokes strong reluctance in the society, because citizens continually lose their trust in the reformers.

Another illustration of the public finance reform is the old-age and disability pension system reorganized in 1999. It was decided to base the system upon three pillars having different sources of funding. Hopes were expressed that the changes would propel economic growth as a result of investment activities carried out by pension funds being part of pillars two and three.

The expectations were again not to be fulfilled. Pension funds turned out to be a relatively inactive vehicle. The IT system allowing the establishment of beneficiaries' individual accounts was not completed. As an intermediary body responsible for collecting contributions and making payments, the Social Insurance Institution proved to be a rather ineffective and costly operator.

Again, the reform was justified by the need to provide the disabled and the elderly with better living conditions, and again the result was disillusionment of the public.

Although many other examples of actions intended to reform the public finance sphere in Poland could be given, for instance those arising from analyses of the functioning of funds and agencies, the above cases seem persuasive enough. The "low-cost state" slogan promoted by the previous government is certainly unacceptable to the public, especially that despite the declared reduction in, for instance, amounts allocated to the state administration, its implementation affects social services and deteriorates the well-being of the population.

Another issue worth bringing up in this context is the present actions of the government and how changes are being interpreted today. "A friendly state" has become a paramount slogan encapsulating changes proposed in "A Convergence Program"11 announced in March 2008 and spanning the years 2008-2010. The document stresses two points:

1) the excessive budget deficit must be reduced from $3.8 \%$ to $1.5 \%$ of GDP, and the public debt level brought down to $42.3 \%$ of GDP in 2010 .

2) a smaller tax wedge. 
The two lines of action are expected to entail considerable costs amounting to $1.3 \%$ of GDP ${ }^{12}$

There are also plans to introduce two rates of the personal income tax in 2009, an income tax threshold equal to PLN 84,426, a tax free amount of PLN 556.02, and tax deductible expenses amounting to PLN 1,335. ${ }^{13}$

In addition to the presented solutions, it is also proposed to terminate the early retirement program and to make bridging pensions available to persons who must leave the labor force for health reasons.

Regarding the restructuring of budget expenditure, larger allocations to development-boosting activities, including science, are predicted.

However, this is another document that does not bring forward any specific solutions that might contribute to reformation of the farmer insurance system.

As a new convergence program will be probably presented in October 2008 more changes can be expected, not necessarily consistent with those presented in its March edition.

\section{Conclusion}

The outlined concepts and doctrines on the state, which are translated into the language of slogans synthetically describing the character of the state and then broadcast by successive governments, constitute the basis for explaining the public finance reforms. However, the real-life examples of implemented improvements reveal a considerable gap between the two ends.

Considering the circumstances, it is worth analyzing what gives the impulse for reforming public finance, and how the reforms relate to the promoted slogans aimed at winning over the voters and public approval.

Public finance reforms are induced by objective factors, but governments translate them using specific and frequently populist phrases that refer to the prevailing feature of the state. Hence, the following relationships are typically stressed:

1. A central authority emphasizing democracy as the state's cornerstone tends to explain public finance reforms by stating that the representative bodies are endowed not only with law-making powers, but they are also obligated to 
control revenues and expenditure, so they must have control over the goals and amounts of the redistributed public funds.

2. In a state that defines itself as a community observing civil society principles reforms are explained with the necessity to provide egalitarian access, i.e. ensuring equal chances, to public goods.

3. A state calling itself a social state claims that reforms are needed because the market is not an instrument helpful in molding a socially desired consumption that might ensure society's well-being.

4. When the "low-cost state" slogan is stressed in a state, then the reforms are presented as an attempt at diminishing costs necessary to service the public sector, particularly these areas of the sector, where the effectiveness of allocations cannot be precisely established.

5. A state promoting the phrase "friendly state" declares that reforms are needed because the public sector is a better manager, especially in some specific areas, and so the services will be more effective. The expected result is social and political support for those who are currently in power. It is regrettable that the turn of the 1980s and 1990s was not sufficiently utilized to gain public support for radical improvement of public finance. 


\section{Streszczenie}

Niniejszy artykuł obejmuje dwa tematy ściśle powiązane ze sobą. Pierwszy odnosi się do potrzeby i niemożności ucieczki przed reformą finansów publicznych w Polsce, gdzie kryzys jest właśnie obserwowany. Drugi z tematów wskazuje, że potrzeba reformy jest uzasadniona przez różne hasła, które wywodzą się z określonych doktryn ekonomicznych i które odzwierciedlają główne cechy państwa.

Artykuł, na podstawie analizy konkretnych przykładów, uzasadnia dlaczego reforma finansów publicznych jest tak niezbędna. 